\title{
Geoparks-geological attractions: A tool for public education, recreation and sustainable economic development
}

\author{
UNESCO, Division of Earth Sciences, 1, rue Miollis, F-75732 Paris Cedex 15, France.
}

\begin{abstract}
Within the framework of an international meeting, held at UNESCO headquarters in Paris on 13 February 2004, the "Operational Guidelines for National Geoparks seeking UNESCO's assistance" and recommendations were presented in their final version.

A global "UNESCO Network of National Geoparks" was established. The aim of this network is to provide a platform of cooperation and exchange between experts and practitioners in geological heritage matters under the umbrella of UNESCO. The network spans all regions of the world and shall bring together groups that share common values, interests, or backgrounds. The International Network of National Geoparks under UNESCO shall serve to develop models of best practice and set standards for territories, which integrate the preservation of geological heritage into a strategy for regional economic development.
\end{abstract}

\section{Background and introduction}

More and more countries have started to develop schemes for recognizing important geological and geomorphological sites or landscapes within their national boundaries. Such Earth heritage sites are important for educating the general public in environmental matters. They also serve as tools for demonstrating sustainable development and for illustrating methods of site conservation whereby recalling that rocks, minerals, fossils, soils, landforms and landscapes are both the products and records of the evolution of our planet Earth and, as such, form an integral part of the natural world.

For a number of years now, and particularly since the United Nations Conference on Environment and Development held in Rio de Janeiro in 1992, where Agenda 21, the Agenda of Science for Environment and Development into the 21st Century, was adopted, the protection and enlightened management of the environment have been widely acknowledged as a top priority. UNESCO, the United Nations Organisation for Education, Science and Culture, contributed to this priority by promoting the protection and sustainable development of geological heritage through mainly two independent programme frameworks, the World Heritage Convention and bilateral cooperation in geological heritage matters through its Division of Earth Sciences.

Through the international convention adopted by UNESCO in 1972 "Concerning the Protection of the World Cultural and Natural Heritage", the World Heritage Committee identifies and monitors properties of outstanding universal value and decides which proper- ties are to be included on the World Heritage List. The criteria guiding the World Heritage Committee for the selection of these sites are extremely strict. The sites included on the World Heritage List have to be of outstanding universal value exclusively, as stipulated in the Convention's Article 2 of natural heritage: "geological and physiographical formations and precisely delineated areas which constitute the habitat of threatened species of animals and plants of outstanding universal value from the point of view of science or conservation".

As of today (July 2004), a total of 788 sites have been inscribed on the World Heritage List, of which 611 are cultural properties, 154 are natural and 23 mixed. Only some 20 are inscribed primarily for geological interest. Among the outstanding sites currently inscribed on the World Heritage List are inter alia the Grand Canyon, the Carlsbad Caverns, the Hawaii Volcanoes, the Mammoth Cave, the Yellowstone Park, and the Yosemite-National Park (in the United States), the Rocky Mountain Parks, and the Dinosaur Provincial Park (both in Canada), the Great Barrier Reef, Shark Bay, the UluruKata Tjuta (Ayers Rock) National Park, Macquarie Island, and the Fossil Mammal Sites of Riversleigh and Naracoorte (all in Australia), the Scocjan Caves (Slovenia), the Caves of the Aggtelek Karst (Hungary and Slovak Republic), the Aeolian Islands (Italy), the Dorset/East Devon Coast and the Giant's Causeway (United Kingdom), the Pirin National Park (Bulgaria), Lake Baikal and the Kamchatka Volcanoes (Russia), Monte San Giorgio (Switzerland) and the Messel Pit Fossil Site (Germany).

The objective of the World Heritage Convention is to recognize natural and cultural sites of "outstanding universal value". As a consequence, the convention will identify only a limited number of geological sites around the world. The World Heritage List is predicted eventually to contain up to 1500 sites in all (cultural plus natural). The assumed scenario suggests that the World Heritage List will eventually accommodate additional $50-100$ new sites nominated primarily sites of paramount geological/geomorphological interest. Seen on a worldwide scale, this is ridiculously little. What should be done with the numerous sites, which are also geoscientifically fascinating, but only of national and local value and do not meet the strict criterion of the World Heritage List to be "globally outstanding"? An alternative was required to meet this demand.

The Geopark concept was developed by several sources, mainly European ones, in strong cooperation with UNESCO about ten years ago. The large number of requests UNESCO has received from all over the world during recent years, from geological institutions and geoscientists and non-governmental organizations, reflected the rising need for a global initiative to promote those geological heritage areas, which are at present recognized only nationally or not recognized at all. After a period of consultation and preparation, the Division of Earth Sciences of UNESCO presented a new concept named UNESCO's "Geoparks Programme" to the governing bodies of the Organization. The Programme has been discussed since 1999 three times by the Executive Board of UNESCO, which came to its final conclusion in June 2001. Although high importance was attached to geological heritage matters, the delegates-driven by the actual budgetary constraints and needs for concentration- 
decided not to pursue the development of a new Geoparks Programme. But, on the other hand, UNESCO's role was considered as crucial in enhancing public awareness of geological heritage issues, achieving their fullest international recognition, and securing their most effective political impact. Therefore, the Division of Earth Sciences continued to pursue the general objective of "Education in Earth Sciences", through the promotion of geological heritage activities, and provided UNESCO's cooperation or assistance to national initiatives on an ad hoc basis when requested by Member States.

Few international programmes exist today, which offer the ability to identify, protect and promote areas or landscapes of geological and geomorphological importance. Taking into account their common goals of pursuing activities in educating the public at large on the environment, promoting regional sustainable development, supporting training and development of scientific research in various disciplines of Earth Sciences, the Division of Earth Sciences of UNESCO has established close ties of cooperation with the European Geoparks Network. UNESCO, on the one side, offers its sponsorship to interested Member States to recognize, protect and enhance Earth heritage sites at the global level, whereas the European Geoparks Network, on the other side, focuses on European sites. This new potential for interaction between socio-economic development and conservation of the natural environment adds a new dimension to the scheme of the World Heritage List. It recognizes as central principle the relationship between people and geology and the ability of a site to serve as a focus for economic development, particularly through geotourism. (Such sites will normally represent landscape elements rather than small geological outcrops of limited area extent.)

With respect to sustainable development, numerous areas in the world offer immediate potential for substantial economic development because of the presence of a diverse range of geological phenomena including, amongst many others, structures, minerals and fossils. Geological heritage sites, properly managed, can generate employment and new economic activities, especially in regions in need of new or additional sources of income. Recalling the United Nations' Millennium Declaration, in particular the assertion of the fundamental value of "Respect for Nature" in the management of all living species and natural resources, we are glad to note that all around the world, there is growing public awareness of the necessity for the conservation of nature; and, fortunately, more and more people recognize that geological features play an essential part in managing our environment in a "wise" way.

\section{Operational activities}

National Geoparks seeking UNESCO's assistance have been invited to send their applications respecting guidelines and criteria agreed upon by a UNESCO International Advisory Group for Geoparks to the Division of Earth Sciences.

The Group was created by UNESCO in consultation with the Scientific Board of the International Geosience Programme (IGCP) in the follow-up of the 31st International Geological Congress, Rio de Janeiro 2000. It consists of geoscientists representing governmental as well as non-governmental organizations from the Americas, Africa, Asia/Oceania, and Europe, as well as the International Geoscience Programme (IGCP), International Union of Geological Sciences (IUGS) and International Geographical Union (IGU).

\section{Members are (2004):}

Prof. James Teller, Canada

Prof. Victor Ramos, Argentina

Dr. Emmanuel Teixeira, Brazil

Prof. Sospeter Muhongo, Tanzania

Prof. Henri Kampunzu, Botswana

Prof. Zhao Xun, China

Prof. Ibrahim Komoo, Malaysia

Dr. Susan Turner, Australia
Dr. Tony Weighhell, United Kingdom

Prof. Friedrich-Wilhelm Wellmer, Germany (EuroGeosurveys)

Dr. Ulrike Mattig, Germany

Dr. Irini Theodossiou-Drandaki, Greece

Dr. Werner Janoschek, Austria

Dr. Prof. José Palacio-Prieto, Mexico, IGU

Liaison members (European Geoparks Network):

Dr. Patrick McKeever, Ireland

Dr. Guy Martini, France, Spain

Prof. Nickolas Zouros, Greece

Ex-officio:

IGCP Board Members

\section{General and selected criteria}

Geoparks under UNESCO's assistance shall:

- preserve geological heritage for future generations (conservation)

- educate and teach the broad public about issues in geological landscapes and environmental matters (education) and provide research facilities for geosciences

- ensure sustainable development (tourism)

(1) Geoparks (requesting the assistance of UNESCO) operate in synergy with other national and international programmes, including the World Heritage Convention and the Man and Biosphere (MAB) Reserve programme-and are complementary to the recently established IUGS-IGU-UNESCO Task Force "GEOSEE".

(2) A Geopark is:

"a territory with well-defined limits that has a large enough surface area for it to serve local economic development. The Geopark comprises a number of geological-palaeontological heritage sites of special scientific importance, rarity or beauty; it may not be solely of geological-palaeontological significance but also of archaeological, ecological, historical or cultural value".

(3) The importance of size and function of a Geopark is described as follows:

a) In principle, a Geopark shall represent a terrain (a landscape), which is of sufficient size to generate economic activitynotably through tourism. Small outcrops, although scientifically important, will not normally have this potential.

b) A Geopark would normally be of sufficient size to encompass a number of small sites (geosites) which, taken together, illustrate important geological features. Such a network in the context of a Geopark would serve to stimulate economic development.

c) A Geopark would comprise a number of geological-palaeontological heritage sites of special scientific importance, rarity of beauty, may not be solely of geological-palaeontological significance. Archaeological, ecological, historical or cultural features could also represent and should be regarded as important components of a Geopark.

d) Terrains which are of geological-palaeontological (and archaeological and biological) interest but which have no permanent population, or are too remote to generate economic activity would also not normally be suitable as Geoparks. The Geopark concept is designed to relate people to their geological-palaeontological and geomorphological environment.

e) A Geopark also has to provide for education on the environment, training and development of scientific research in the various disciplines of the Earth Sciences, enhancement of the natural environment and sustainable development policies.

The impact on the area is immediate, by improving human living conditions and the rural environment, strengthening identification of the population with their area and triggering cultural renaissance. Respectful of the environment, Geoparks stimulate, for example, the creation of innovative local enterprises, small businesses, cottage industries and new jobs, generate new sources of revenue 
(e.g. geotourism, geoproducts). This provides supplementary income for the local population and attracts private capital.

Twenty five National Geoparks (17 European and 8 Chinese) have been evaluated in February 2004 and are, at the moment, members of the UNESCO Network.

\section{(P.R. China)}

1. Huangshan Geopark

2. Lushan Geopark

3. Yuntaishan Geopark

4. Shilin Stone Forest Geopark

5. Danxiashan Geopark

6. Zhangjiajie Sandstone Peak Forest Geopark

7. Wudalianchi Geopark

8. Songshan Geopark

\section{(Europe)}

9. Réserve Géologique de Haute Provence-France

10. Petrified Forest of Lesvos-Greece

11. Vulkaneifel European Geopark-Germany

12. Maestrazgo Cultural Park - Spain

13. Psiloritis Park-Greece

14. Rochechouart Chassenon Astroblème-France

15. Nature Park Terra Vita European Geopark-Germany

16. Coper Coast-Ireland

17. Marble Arch Caves \& Cuilcagh Mountain Park-

Northern Ireland-United Kingdom

18. Madonie Natural Park - Italy

19. Rocca di Cerere Cultural Park - Italy

20. Kamptal Geopark - Austria

21. Nature Park Eisenwurzen-Austria

22. Cabo de Gata Natural Park-Spain

23. Bergstrasse-Odenwald Geopark - Germany

24. North Pennines Geopark - United Kingdom

25. Abberley and Malvern Hills Geopark-United Kingdom

Five additional Geoparks are being expected to complete this list: three of Germany (Harz-Ostfalen; Swabian Alb; Mecklenburg), one of Italy (Sardinia), and one of Switzerland (Sargans).
Wolfgang Eder, Geology studies at the universities of Tübingen, Göttingen and Münich; PhD. 1970 in Geology, Geochemistry and Geophysics with a sedimentological thesis on Devonian Carbonate Turbidites at Göttingen University. Paleogeographic and geodynamic researcher, lecturer and coordinator of European Variscan and African Damaran interdisciplinary projects (1970-1981); Geoscientific Secretary of joint Earth science research projects at the German Science Foundation, national Secretary of international Lithosphere, Continental and Ocean Drilling Programmes and the IGCP (1982-1991). Since 1992, UNESCO Director of the Division of Earth Sciences, and IGCP Secretary.

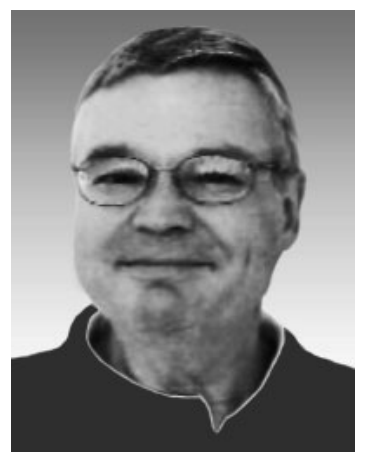

Margarete Patzak, Studies of Geology and Mineralogy at the Universitiy of Würzburg, Germany. Ph.D. 1991 in Mineralogy with a petrological thesis on Metabasites of the German Deep Continental Drilling Project "KTB". Coordinator of European projects on protection and conservation of cultural heritage (EUROCARE), based at the University of Karlsruhe up to 1995. Since 1996, serving as professional at UNESCO's Division of Earth Sciences and Assistant to the IGCP Secretary.

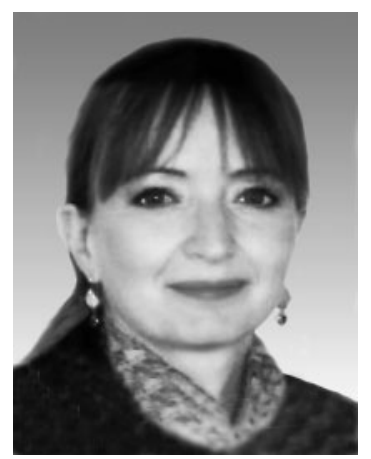

